\title{
ARGENTAFFIN CARCINOMA (CARCINOID TUMOUR) OF OVARY
}

\author{
BY \\ R. WINSTON EVANS, HILDA R. HARRIS, AND CATHERINE D. M. McDOUGALL \\ From the David Lewis Northern Hospital, Liverpool
}

(RECEIVED FOR PUBLICATION JULY 22, 1958)

Carcinoid tumours arising in cystic teratomata of the ovary have been observed by Stewart, Willis, and de Saram (1939), Gabrilove (1941), Blackwell and Dockerty (1946), Mitchell and Diamond (1949), Martin, Féroldi, and Cabanne (1956), and Falkmer (1956). A carcinoid tumour developing in a cystic teratoma of the testis was noted by Simon, McDonald, and Culp (1954).

Hartz (1945), who described a massive virilizing arrhenoblastoma containing cysts and collections of argentaffin-positive cells, interpreted the cyst lining as intestinal epithelium and the large and small groups of silver-reducing cells as carcinoid tissue. It is doubtful, however, whether this growth is acceptable as an ovarian argentaffin carcinoma. Dilated tubules and cysts lined by the mucinous epithelium are not uncommon findings in arrhenoblastoma of intermediate morphology, and, despite the presence of goblet cells and, sometimes, cells exhibiting a silver-reducing capacity, such structures necessarily are not endodermal in nature; they represent, more likely, metaplastic reactions in epithelial elements derived from the mesenchymal substance of the ovary. The interstitial cells in the tumour reported by Hartz exhibited a silver-reducing pigment, and it is probable that the tissue regarded as argentaffin was composed of large and small clusters of such interstitial cells.

If Hartz's case is excepted then the instance described below represents the eighth report of an argentaffinoma arising primarily in the ovary (Table I).

\section{Summary of Clinical Features}

On December 5, 1956, the patient, aged 62 years, and menopausal since the age of 52 years, came to hospital complaining of lassitude, urticaria, pains in both shoulders, flatulence, abdominal discomfort, and loss of weight unaccompanied by an impaired appetite. She also admitted to a return of the "hot flushes" (sometimes initiated by drinking a small quantity of
TABLE I

REPORTED CASES OF PRIMARY ARGENTAFFIN CARCINOMA OF OVARY

\begin{tabular}{|c|c|c|c|}
\hline Author & $\begin{array}{l}\text { Age of } \\
\text { Patient } \\
\text { in Years }\end{array}$ & Brief Clinical Notes & $\begin{array}{l}\text { Tissue of } \\
\text { Origin }\end{array}$ \\
\hline $\begin{array}{l}\text { Stewart et al. } \\
\text { (1939) }\end{array}$ & $\begin{array}{l}68 \\
48\end{array}$ & $\begin{array}{l}\text { Diarrhoea with blood } \\
\text { and mucus for } 5 \text { months } \\
\text { Abdominal pain } 3 \text { years. } \\
\text { Mass in abdomen }\end{array}$ & $\begin{array}{l}\text { Intestinal } \\
\text { derivatives } \\
\text { Intestinal } \\
\text { derivatives }\end{array}$ \\
\hline Gabrilove (1941) & 29 & $\begin{array}{l}\text { Incidental finding at } \\
\text { necropsy }\end{array}$ & $\begin{array}{l}\text { Gastric } \\
\text { mucosa }\end{array}$ \\
\hline $\begin{array}{l}\text { Blackwell and } \\
\text { Dockerty (1946) }\end{array}$ & 59 & $\begin{array}{l}\text { Abdominal pain } 1 \text { year. } \\
\text { Mass in pelvis }\end{array}$ & $\begin{array}{l}\text { Uncertain, } \\
\text { probably } \\
\text { gastro- } \\
\text { intestinal }\end{array}$ \\
\hline $\begin{array}{l}\text { Mitchell and } \\
\text { Diamond } \\
\text { (1949) }\end{array}$ & 63 & $\begin{array}{l}\text { Generalized skin } \\
\text { eruption. Radiograph } \\
\text { showed calcified mass } \\
\text { in pelvis }\end{array}$ & $\begin{array}{r}\text { Respiratory } \\
\text { epithelium }\end{array}$ \\
\hline$\underset{(1956)}{\operatorname{Martin}}$ et al. & 72 & $\begin{array}{l}\text { Pain in abdomen and } \\
\text { lumbar region. Mass in }\end{array}$ & $\begin{array}{l}\text { Intestinal } \\
\text { derivatives }\end{array}$ \\
\hline Falkmer (1956) & 39 & Symptomless & $\begin{array}{l}\text { Respiratory } \\
\text { tract } \\
\text { epithelium }\end{array}$ \\
\hline
\end{tabular}

whisky) which she had experienced at the climacteric. Her symptoms had been present for 12 months.

The cardiovascular and respiratory systems showed no abnormality. A pelvic tumour was found.

At operation on December 7 a large, partly solid cyst was discovered arising from the left ovary and this was removed without difficulty or subsequent complication. On palpating the abdominal organs the surgeon (Sir Arthur Gemmell) noted a nodule, the size of a shirt button, on the surface of the right lobe of the liver.

The patient was seen again on March 25 and 29, September 23, 1957, and January 9, 1958. She felt much better and admitted to having gained one stone in weight and that her "hot flushes" were much less marked.

Physical and radiographic examinations on these occasions revealed no respiratory, cardiovascular, abdominal, or skeletal abnormality. The electrocardiogram was normal and a follow-through barium meal showed no evidence of a gastro-intestinal lesion.

Since the diagnosis of the ovarian growth as a carcinoid tumour, the urine was repeatedly examined for 5-hydroxyindoleacetic acid; such tests, carried out by a qualitative chromatographic technique, have been consistently negative. 


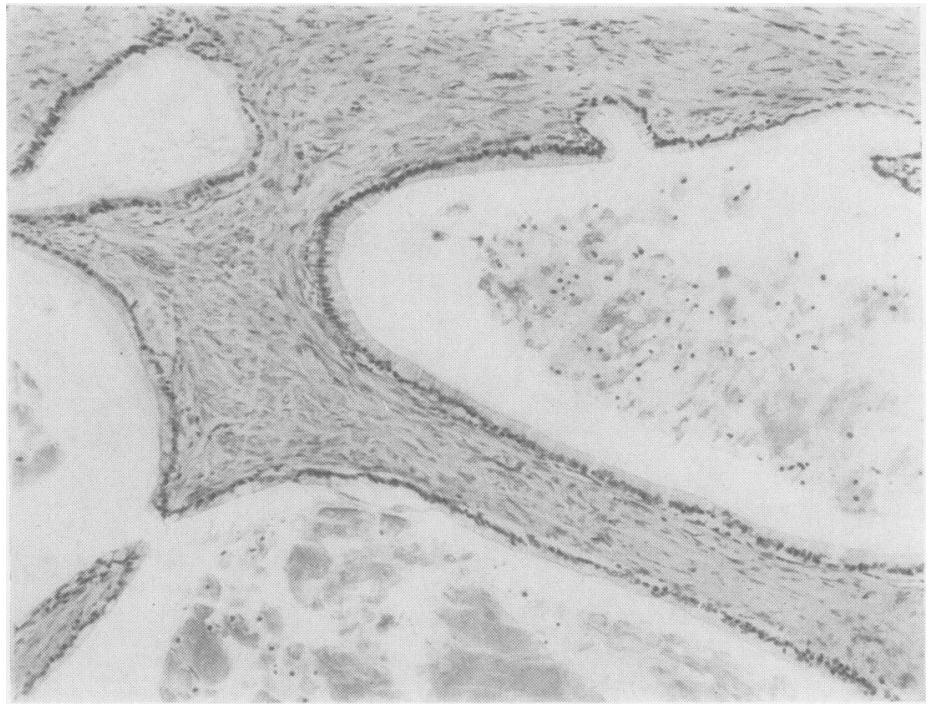

FIG. 1.-Pseudomucinous epithelium lining inner wall of cyst. Haematoxylin and eosin $\times 95$.

FIG. 2.-Occasional argentaffin cell in pseudomucinous epithelium. $\times 250$.

FIG. 3.-Section through poriferous portion of cyst wall. Haematoxylin and $\operatorname{cosin} \times 85$.

Fig. 1

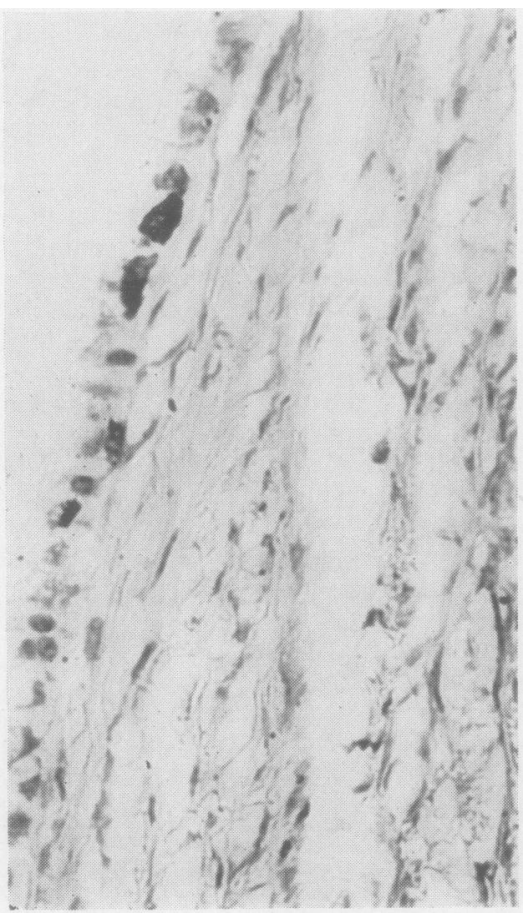

FIG. 2

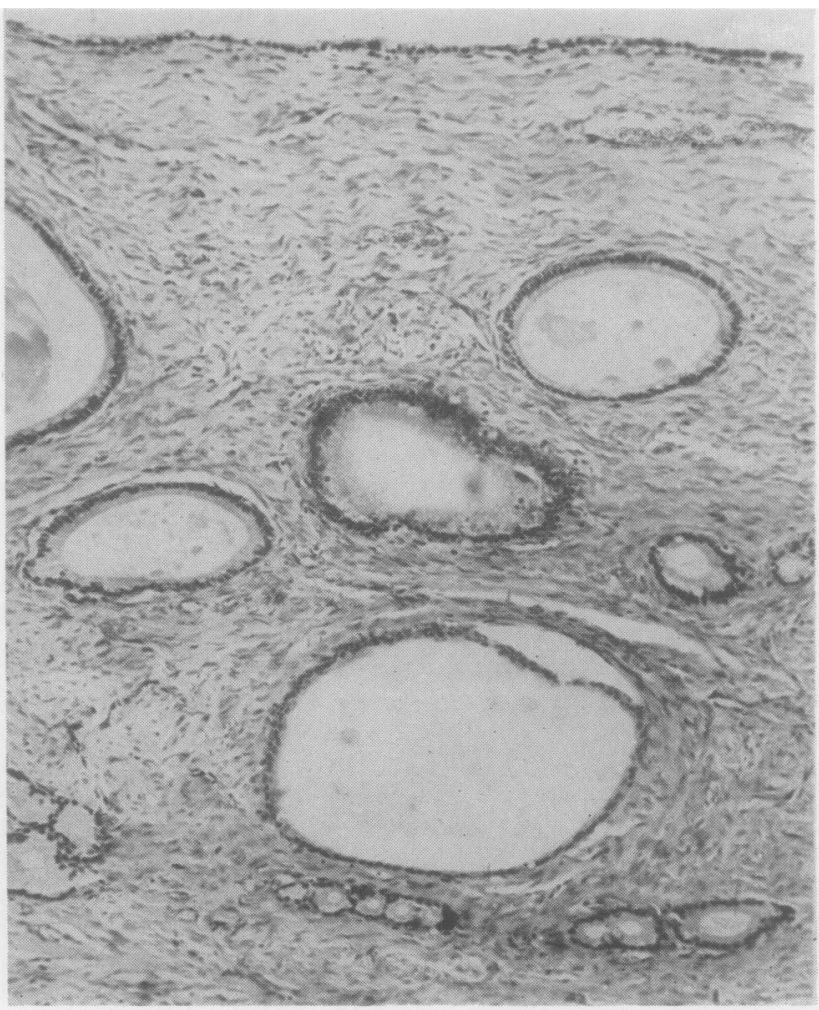

Fio. 3 


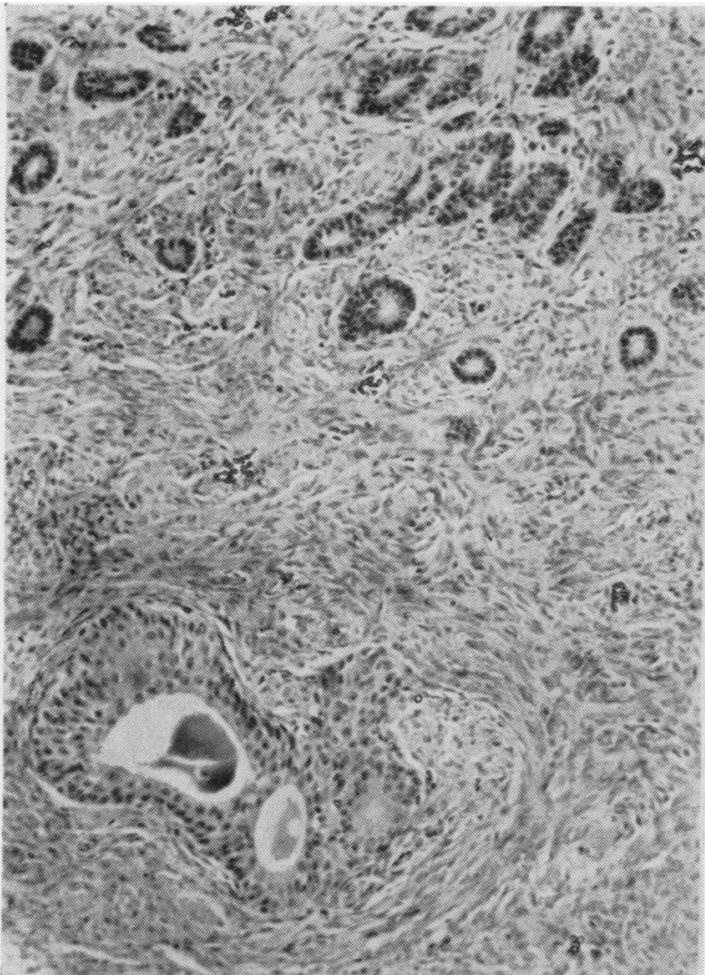

FIG. 4.-Nest of Brenner epithelium surrounded by fibroblastic tissue and glandular elements of gastro-intestinal epithelium. Haematoxylin and eosin $\times 130$.

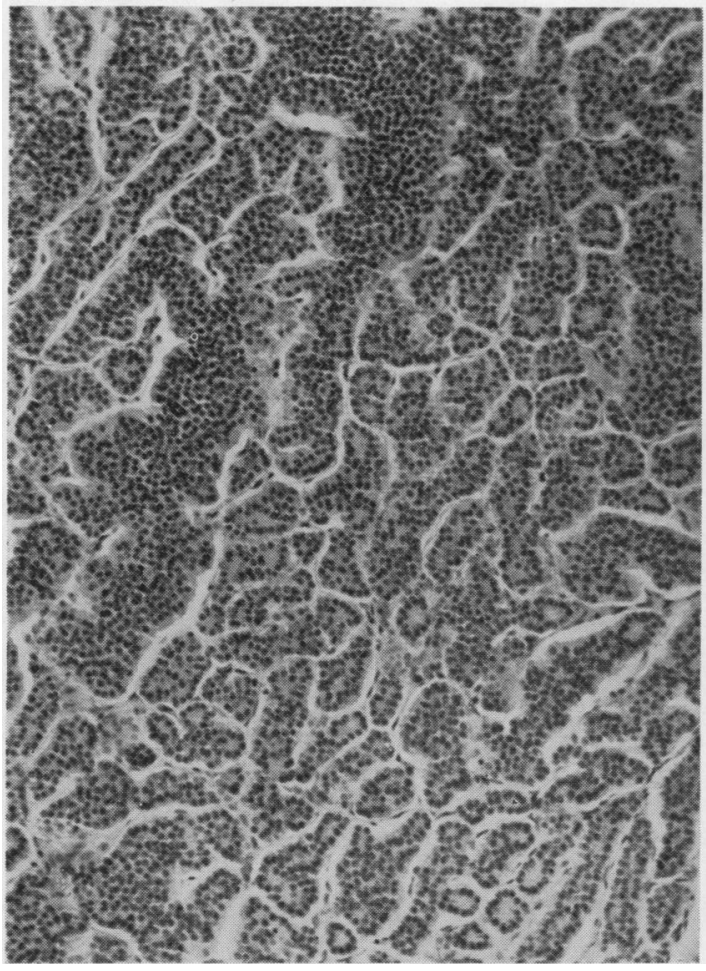

FIG. 6.-Acinar differentiation in sheets and nests of carcinoid cells. Haematoxylin and eosin $\times 120$.

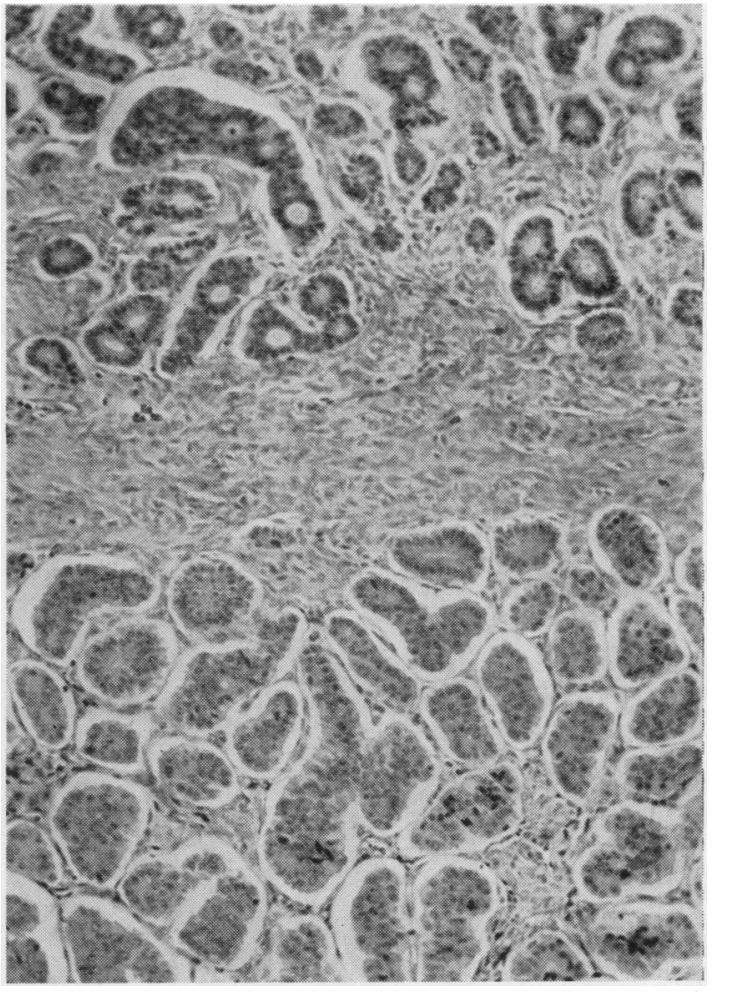

FIG. 5.-Typical compact clumps of carcinoid tissue near acini of gastro-intestinal type. Haematoxylin and eosin. $\times 130$.

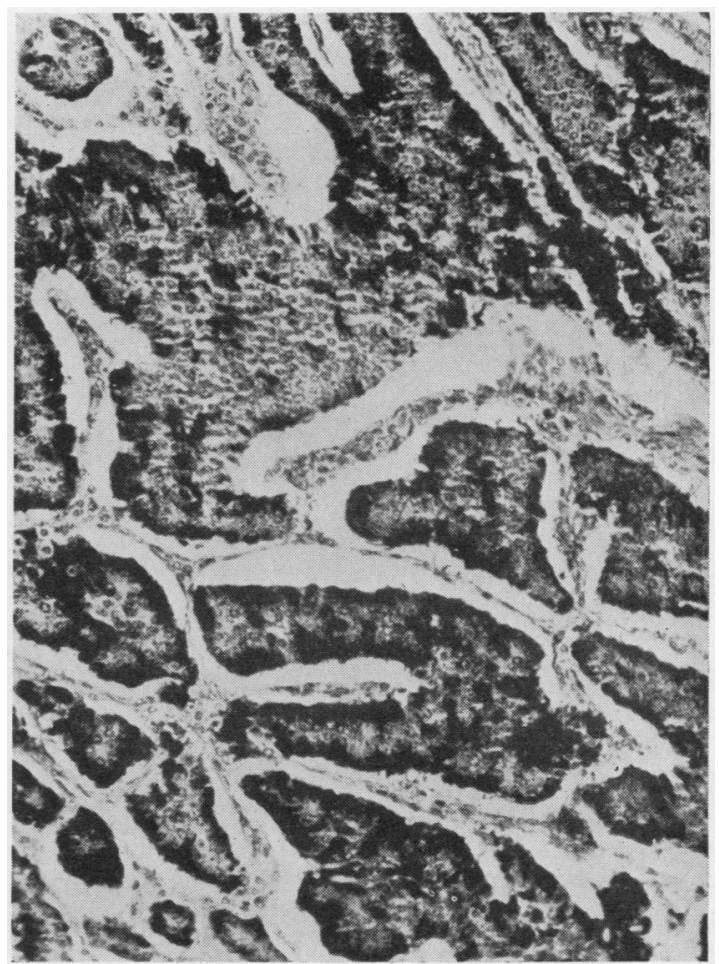

FIG. 7.-Intensely positive argentaffin reaction. Masson's technique. 130. 


\section{The Tumour}

Macroscopic Features.-The smoothly and well encapsulated ovarian cyst measured $20 \mathrm{~cm}$. by $18 \mathrm{~cm}$. by $15 \mathrm{~cm}$. and weighed $132 \mathrm{oz}$. It consisted of one large cavity containing a yellow, turbid, mucinous fluid; occupying a portion of the cyst wall was a distinctly yellow, ovoid, homogeneously solid tumour measuring 10 by 7 by $6 \mathrm{~cm}$. The cyst wall, though thin and stretched, was obviously tough; in the immediate vicinity of the solid mass it was thicker, partly poriferous, and seemingly split into two main layers which encompassed the yellow tumour. The spongy portion consisted of tiny cysts distended by a mucinous fluid, and the inner layer enveloping the solid tumour was intact except in one small area where the yellow neoplastic tissue, having penetrated through this barrier, protruded in warty fashion into the main cavity of the cyst.

Histological Appearances.-The solid tumour exhibited in all areas the characteristic microscopic features of an argentaffin tumour (Figs. 5-7), the carcinoid tissue occurring in compact nests, clusters, and irregular sheets within which tiny acini and pseudo rosettes were elaborated frequently. The cells, especially those peripherally placed in the nests and irregular masses, reacted positively with Schmorl's method; they also reacted positively with the diazo and the Gibbs method for argentaffin granules and yielded a strongly positive argentaffin reaction (Masson) (Fig. 5). The typical silver-reducing and histochemical reactions of the carcinoid cells were obvious and easily elicited in most areas of the tumour; in some parts the reactions were weak and here and there were indifferent and equivocal.

No gastro-intestinal or bronchial structure as such was identified, but in the peripheral borders of the mass there were collections of glandular elements, not unlike atypical gastric epithelium, lined mainly by cuboidal cells. There was, however, no associated smooth muscle, and the acini, in some areas (Fig. 5) separated by fibrous tissue from the more obviously carcinoid tissue, were, in others, intimately related. Such tubular and acinar elements also contained argentophil cells.

The lining of the main cyst either was not recognizable as an epithelial layer or was extremely attenuated and composed of flattened cells. In the poriferous areas near the solid tumour, however, there were small mucinous cysts lined by tall columnar cells with parallel sides and basal nuclei, generally resembling those of pseudomucinous epithelium (Figs. 1-3). Argentaffin cells in the epithelium of these microcysts were extremely scanty (Fig. 2) and very widely dispersed. Although many areas were examined, nowhere could it be established that the carcinoid tissue was in continuity or even in juxtaposition to this pseudomucinous epithelium.

Near the capsule of the cyst and forming part of the solid tumour there was a microscopic nodule of fibroblastic tissue containing nests of typical Brenner epithelium (Fig. 4). The cells in these nests did not reduce silver solutions neither did they react when treated with the diazo and the Gibbs method for argentaffin granules. The nuclear morphology was entirely different from that of the carcinoid cells-many of the nuclei in the clumps of Brenner epithelium exhibiting the characteristic coffee bean appearance. Although a few Brenner nests were cystic none contained a mucinous type of epithelium.

Epidermoid structures, muscle, cartilage, and bone were completely absent from any part of the cyst or solid tumour.

\section{Discussion}

The structural features and staining reactions of the solid portion of this predominantly cystic ovarian growth are characteristic of carcinoid tissue. The argentaffin reaction, though fickle and in itself not absolutely specific for carcinoid tumours, nevertheless can be considered conclusive when supported by a battery of histochemical reactions such as those elicited by the diazo, Gibbs, and Schmorl techniques.

Despite the argentaffin nature of the neoplastic tissue, in the absence of evidence obtainable only at necropsy, it might be argued that the growth represents a secondary, not a primary, carcinoid tumour of the ovary. Unlike the majority of instances of secondary ovarian carcinoid tumours, however, the growth in this case was a unilateral gonadal tumour; in addition, the origin of the argentaffinoma from a gastro-intestinal type of epithelium included in the wall of this cystic ovarian teratoma was clearly demonstrable on microscopy.

In the reported instances of primary ovarian carcinoid tumours the growths have arisen from either gastro-intestinal or respiratory epithelium in dermoid cysts. The case described in this communication appears to be the first occasion when such a carcinoid tumour has been observed to originate in association with a pseudomucinous cyst, particularly one which also contained within its wall a Brenner tumour of microscopical 
dimensions. The full potentialities of the ovarian stroma remain largely undisclosed so that the histogenetic implications of the association of pseudomucinous epithelium with teratoid elements is difficult to evaluate. Nevertheless the possibility that a pseudomucinous cystadenoma may arise as an exaggerated development of the endodermal component of a teratoma must be admitted even though conclusive evidence of such a mode of origin is not yet available. Although the teratoid theory of genesis of pseudomucinous epithelium is considered tenable but unproved, it is not suggested that in this case such an epithelium, together with the gastro-intestinal epithelium, the argentaffinomatous tissue, and the very small Brenner tumour, are all elements of a single teratomatous growth. No direct continuity between the carcinoid and gastro-intestinal elements, on the one hand, and the pseudomucinous lining on the other hand could be established, and it is likely that, whereas the gastrointestinal epithelium and the argentaffinoma arising from it are teratomatous in nature, the accompanying pseudomucinous cystadenoma is of independent origin.

The "hot flushes" experienced by the patient became progressively less marked after the removal of the ovarian teratoma; yet they are of considerable interest because of their association with a large argentaffinoma. Although no direct proof exists the possibility remains, nevertheless, that this symptom might have been accompanied by a pre-operative, high urinary output of 5hydroxyindoleacetic acid. Perhaps, on account of its large bulk, the teratomatous argentaffinoma was capable of secreting humoral agent in sufficient quantities to cause these episodic flushes, so characteristically exhibited in the carcinoid syndrome.

Primary argentaffinomatous tumours of the intestine, by the time the carcinoid syndrome is established, usually have produced intrahepatic secondary deposits. In the case of the primary ovarian tumour discussed in this communication, post-operative tests for 5-hydroxyindoleacetic acid were repeatedly negative, suggesting that the growth, before its removal, probably had not produced many, if any, gross metastases.

\section{Summary}

An argentaffinoma arising primarily in an ovarian teratoma associated with a pseudomucinous cyst is described. It is believed the case represents the eighth instance in which a carcinoid growth has been observed to arise primarily in the ovary.

For his interest and for allowing access to the clinical notes we are very grateful to Sir Arthur Gemmell, M.C., T.D., M.A., M.D., F.R.C.S.Ed., F.R.C.O.G.

\section{REFERENCES}

Blackwell, W. J., and Dockerty, M. B. (1946). Amer. J. Obstet. Gynec., 51, 575 .

Falkmer, S. (1956). Cancer, 9, 727.

Gabrilove, J. L. (1941). Arch. Path. (Chicago), 31, 503.

Hartz, P. H. (1945). Amer. J. Path., 21, 1167.

Hopping, R. A., Dockerty, M. B., and Masson, J. C. (1912). Arch. Surg. (Chicago), 45, 613.

Martin, J. F., Féroldi, J., and Cabanne, F. (1956). Ann. Anat. path., n.s., 1, 19

Mitchell, N., and Diamond, B. (1949). Cancer, $2,799$.

Simon, H. B., McDonald, J. R., and Culp, O. S. (1954). J. Urol (Baltimore), 72, 892.

Stewart, M. J., Willis, R. A., and Saram, G. S. W. de (1939). J. Path. Bact., 49, 207. 